\title{
Bioelectricity Generation From Single-Chamber Microbial Fuel Cells With Various Local Soil Media and Green Bean Sprouts as Nutrient
}

\author{
Tri Mulyono ${ }^{a^{*}}$, Misto $^{\mathrm{b}}$, Busronia $^{\mathrm{a}}$, Siswanto $^{\mathrm{c}}$ \\ ${ }^{a}$ Department of Chemistry, Faculty of Science and Mathematics, University of Jember 68121, Indonesia \\ ${ }^{b}$ Department of Physic, Faculty of Science and Mathematics, University of Jember 68121, Indonesia \\ 'Department of Biology, Faculty of Science and Mathematics, University of Jember 68121, Indonesia
}

\begin{abstract}
In this experiment, seven single-chamber microbial fuel cells (MFCs) were made and filled with various types of local agricultural soil and sediments found in irrigation channels, which were mixed with glucose and green bean sprouts mashed as nutrients for microbial survival. MFC electric power was measured every day for 35 days. Every time low electric power indicated weak microbial activity, green bean sprouts were added. The highest electric power of $118 \mu \mathrm{W}\left(23.4 \mu \mathrm{W} / \mathrm{m}^{2}\right) \mathrm{was}$ observed in fuel cells filled with agricultural land planted with rice. Power density reached the range of $120-140 \mathrm{~mW} / \mathrm{m}^{2}$, whereas the incubation time showed a maximum of 35 days. This study found that adding green bean sprouts can increase the length of the MFC cycle and strengthen the generated power up to $122 \mu \mathrm{W}$. C2020. CBIORE-IJRED. All rights reserved
\end{abstract}

Keywords: Local soil, redox, media, microbial fuel cell, incubation

Article History: Received: $8^{\text {th }}$ March 2020; Revised: $19^{\text {th }}$ June 2020; Accepted: $1^{\text {st }}$ July 2020; Available online: $15^{\text {th }}$ July 2020

How to Cite This Article: Mulyono, T., Misto, Busroni, and Siswanto. (2020) Bioelectricity Generation from Single-Chamber Microbial Fuel Cells With Various Local Soil Media and Green Bean Sprouts as Nutrient. International Journal of Renewable Energy Development 9(3), 423-429 https://doi.org/10.14710/ijred.2020.30145

\section{Introduction}

Producing energy from organic waste is becoming increasingly important because energy production from fossil fuels has become more expensive and not environmentally friendly, and this causes climate change problems. Microbial fuel cells (MFCs) present as an alternative environmentally friendly technology to produce bioelectricity directly from materials that naturally decompose, such as organic acids, proteins, and carbohydrates (Chaturvedi \& Verma, 2016), (Parkash, 2016). However, there are still some obstacles in the commercial production of these cells, such as the cost of fuel cell construction, the problem of increasing size, and the problem of increasing the ability to produce power density and contribute to an increase in output voltage. In MCF systems, the configuration of the anode and cathode catalyst can play a crucial role in improving the power density. Other important technical parameters in the design of MFCs include the distance of the two electrodes from the fuel cell (Logan \& Rabaey, 2012; Pant et al., 2011; Choudhury et al., 2017), the anode and the cathode membrane separator (Biffinger et al., 2007), the use of membrane-electrode assembly (Park, 2000), cathode type
(Cheng et al., 2011),(Rahimnejad et al., 2015), (Ömeroğlu \& Sanin, 2016), and the operating conditions of the system being operated, including $\mathrm{pH}$ (Zhang et al., 2013) as well as the sustainability of batch versus flow system operation. Research on power density values in the range of $1-2.4 \mathrm{~W} / \mathrm{m}^{2}$ has been published with regard to the design of the MFC, with the addition of several parameters (Logan et al., 2015; Helder et al., 2012). The production of MFCs has several advantages when compared with material cell production, such as low cost and the absence of toxic mediators. For instance, a good system can be successfully made without the use of expensive selective membranes. The use of mixed membrane materials has been investigated in a number of articles about MFCs, and more recently, bioelectricity has been produced using energy sources from wastewater (Tharali et al., 2016). With this substrate, the power density that can be produced by MFCs is in the range of $10-14 \mathrm{~mW} / \mathrm{m}^{2}$, whereas MCFs that use mixed media are reportedly producing slightly larger power density values from 0.3 to $3600 \mathrm{~mW} / \mathrm{m}^{2}$. Several researchers conducted a study by inserting artificial waste water into a reactor $(\mathrm{He}$ et al., 2016; Xu et al., 2016; Asai et al., 2017) with mud media, and they observed a 20 -fold increase in current

\footnotetext{
* Corresponding author: arekkramat@gmail.com
} 
density over 30 days, which made it possible to select beneficial organisms, even though the power density produced was not large enough at $1.3 \mathrm{~mW} / \mathrm{m}^{2}$.

Microbial fuel cells have previously used a twocompartment system, where aerated cathode compartments contain chemical solutions of iron and oxygen and anode compartments contain bacterial cells, electron mediators, and reduced substrates (Ucar et al., 2017; Song et al., 2019). Other soil substrate materials, such as paddy soil and river sediments, have been reported (Aziz, 2015; Xia et al., 2017).

In MFCs, the substrate is one of the most critical factors that can influence bioelectricity generation because it functions as a source of nutrition and energy for the growth of the microorganisms involved. In most MFC studies, pure compounds, such as glucose (Rabaey et al., 2003), amino acids from cysteine (Logan et al., 2005), and ethanol (Kim et al., 2007), have been used for electricity generation. Other compounds that have been used include complex substrates, such as domestic wastewater (Liu et al., 2009), starch processing wastewater (Min \& Logan, 2004), and marine sediments (Min \& Logan, 2004). The mixture of organic compounds in wastewater has provided information that a diverse microbial community plays an essential role in oxidizing organic matter because most exo-electrogenic bacteria can only survive if supported by various types of substrates (Wrighton et al., 2010).

Therefore, this study aims to evaluate the potential of local rice fields and river sediments mixed with plastic soil in enhancing the bioelectricity produced by MFCs and maintain the survival of MFCs by adding softened mung bean sprouts as a nutrient. We chose to use mung bean soy sauce as a nutrient in the MFC system because it contains vitamin $\mathrm{C}$ compounds, B-carotene, free amino acids, and reduced levels of flatulence-causing oligosaccharides and mineral-binding phytic acids (Liu, 2008).

\section{Materials and Methods}

\subsection{Cultivation and activation of bacteria}

Bacterial growth stages, bacterial cell preparation by Escherichia coli, and metabolite measurements were carried out according to Cao et al. (2006). E. coli bacteria were anaerobically planted for 24 hours in a media at 37 ${ }^{\circ} \mathrm{C}$. The media consisted of $10.00 \mathrm{~g} / \mathrm{L}$ of D-glucose $(\geq 99.5 \%$ (GC) Sigma-Aldrich), $5.00 \mathrm{~g} / \mathrm{L}$ of yeast extract (Granulated Millipore), $8.50 \mathrm{~g} / \mathrm{L}$ of $\mathrm{NaH}_{2} \mathrm{PO}_{4}$ (BioXtra, $\geq 99.0 \%$ SigmaAldrich), and $10.00 \mathrm{~g} / \mathrm{L}$ of $\mathrm{NaHCO}_{3}$ ( $\geq 99.7 \%$ SigmaAldrich) under nitrogen-carbon dioxide gas (85:15) in a $250-\mathrm{ml}$ bottle, which resembles $100 \%$ atmospheric nitrogen in a fuel cell system whose $\mathrm{pH}$ value is controlled (Zhang et al., 2007). Glucose is added to the media after being treated in an autoclave. The results of this suspension are obtained by taking a phase-stationary culture at $4{ }^{\circ} \mathrm{C}$ through centrifugation at a speed of 5500 rpm (Rolfe et al., 2012). The suspension that contains the cells is washed twice with a phosphate buffer solution that has a pH level of 7.0. Then, these cells are washed again with the same solution ( $\mathrm{pH} 7.0)$

The research consisted of several stages: (i) preparing samples of various soil types soil from rice paddies and local rivers around paddy fields located in the Kranjingan region, Sumbersari, Jember; (ii) inserting multiple types of soil media into the MFC unit and electrode placement; and finally (iii) measuring the time of incubation and power density of a single-chamber MFC with various types of soil media mixed using glucose at optimal concentrations $(30 \mathrm{~g} / \mathrm{L})$ as a substrate (Jafary et al., 2000).

\subsection{Procedure of single-chamber $M F C$}

Fuel cells are made of plastic in the form of a tube with a diameter of $5 \mathrm{~cm}$ and a height of $7 \mathrm{~cm}$. This fuel system has a pair of electrodes, namely, a cathode and an anode, which are made of carbon fiber. The anode is connected with titanium wire and wrapped in green, whereas the cathode is connected with copper wire. Inside a container containing the substrate, the anode is positioned at a height of $1 \mathrm{~cm}$ from the bottom of the container, whereas the cathode is at a distance of $4.5 \mathrm{~cm}$ from the anode, such that the two electrodes are separated by the soil which serves as a microbial growth medium. Both electrodes are connected to the circuit boards that measure the current and voltage. Figure 1 shows the structure of a singlechamber fuel cell system.

Figure 1(c) shows the placement of an electronic measuring board (MudWatt, Keego Technologies, LLC, USA) on the cover of the MFC container. This board has eight pins that have different functions, as shown in Figure 1(c). The positive sign must be properly linked to the cathode electrode and the negative sign to the anode electrode, whereas pins 1 and 2 should be connected to the capacitor that functions as the LED light indicator (Misto et al., 2019). The other pin is connected to the LED light.

\subsection{Single-Chamber MCF system}

The substrate is a main factor in electricity production in an MCF system. The type of substrate used was an organic compound (i.e., glucose) that can help the growth of active microbes. The types of soil media that were used include organic soil and plastic waste, soil covered with water spinach, fertile soil overgrown with rice, waste soil or land on the irrigation door, protected soil for chili plants, soil found $1 \mathrm{~m}$ away from organic soil + plastic waste, and soil found on a pile of rubbish.

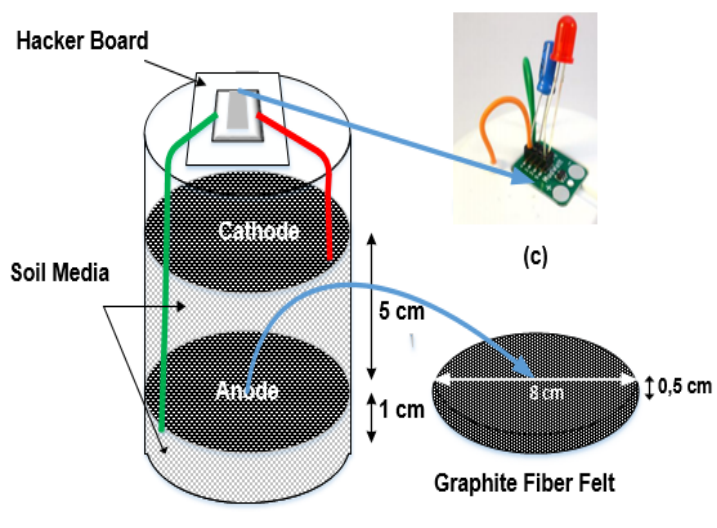

(a)

(b)

Fig 1. (a) Structure of single-chamber fuel cell with anode and cathode; (b) dimension of graphite felt anode; (c) MudWatt board for measuring MFC power. 
The substrate that was filled into the single-chamber MFC compartment was incubated for 7, 14, and 21 days. The time needed by microbes to form a biofilm at the anode is around 7 days (Sultana et al., 2015; Baranitharan et al., 2015). During this period, measurements of current, potential difference, and power output were carried out from the first day to the $37^{\text {th }}$ day (Park, 2000; Aelterman et al., 2008). At 7 days and above, it is expected that the current is strong and the voltage will increase, whereas at 21 days, it is expected that the values will be stable. All measurements were carried out in closed circuit mode with external resistance.

\subsection{Polarization test and data recording}

To determine the polarization characteristics, we needed an external resistance ranging from $10 \mathrm{k} \Omega$ to $10 \Omega$ mounted between the anode and the cathode to produce strong current and voltage between the two electrodes, which are recorded every $60 \mathrm{~s}$ (Koók et al., 2020). From these two quantities, the power output from the MFC will be monitored in real time using an NI USB-6211 multichannel data acquisition unit (National Instrument) every $5 \mathrm{~min}$. This measurement is carried out at room temperature (or $29^{\circ} \mathrm{C}$ ).

The voltage of the fuel cell system is measured using an NI USB DAQ 6211 that has an ADC shield (16 bytes). Similarly, the electricity generated by the system was measured using the NI USB DAQ. Then, the value of this electric quantity was processed so that the electric power $(\mathrm{mW})$ is obtained for each anode surface area. Power density was calculated using Eq. 1 (Marashi \& Kariminia, 2015).

$$
\text { Power }(\mathrm{mW})=\mathrm{V}(\text { volt }) \times \mathrm{I}(\mathrm{mA})
$$

\section{Results and Discussions}

\subsection{Effect of soil type on power at the beginning of incubation}

Seven single-chamber MFCs were operated for 3 days with each type of soil. Using a circuit board, power measurements were taken every day at the beginning of incubation. As shown in Figure 2, the soil from plastic and organic waste and the fertile soil overgrown with rice produce the highest electricity compared to the other types of soil. These are followed by the type of soil on the irrigation door, the soil piled up in garbage, and the soil found within $1 \mathrm{~m}$ from the mixture of plastic and organic waste. Meanwhile, the remaining soil types produce power below $20 \mu \mathrm{W}\left(3.9 \mathrm{~mW} / \mathrm{m}^{2}\right)$.

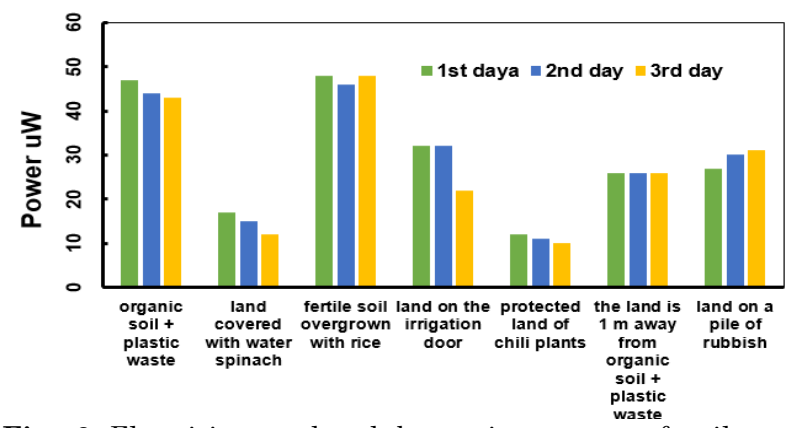

Fig. 2 Electricity produced by various types of soil at the beginning of incubation.
The different soil types were examined together with pure soil, as a reference. Soil that was mixed with waste will produce greater bioelectricity, whereas the reference soil as a control does not produce electricity. The type of pure reference soil is tested to determine that the electric power generated actually comes from the presence of microbial biodegradation activity and not from ionization or redox reactions between elements and minerals in the soil (Totsche et al., 2018). Such results are supported by Fosso-kankeu et al., (2015), who studied the "impact of soil type on electricity generation from a microbial fuel cell." They stated that the low power produced by the configuration of pure clay without compost (organic material) is mainly from microbial activity, although it is slightly increased by the soil. In their research, the results of the power density produced by MFCs reached the highest value of $0.09 \mathrm{~mW} / \mathrm{m}^{2}$. In this study, the results reached approximately $50 \mu \mathrm{W}\left(0.992 \mathrm{~mW} / \mathrm{m}^{2}\right)$.

Furthermore, this study shows that applying fertile rice soil at the beginning of incubation (for 3 days) for energy generation resulted in the maximum effect of energy produced in the MFC (see Figure 3). The next lower maximum energy occurs in the application of soil that was covered by organic waste and plastic. This plastic-covered organic soil is thought to be a suitable environment for microbial growth. The next lower maximum energy was observed in the application of pile soil, which shows a continued increase from the first day to the third day. The next maximum energy occurs in soil applications that come from near the trash (1 $\mathrm{m}$ from the place), which showed consistent results at the incubation phase (days 1 to 3). However, in the other two soil applications, the results were quite low (less than $20 \mu \mathrm{W}$ ) and were not what you would expect at this phase. In this study, a trend of increasing power can be expected in soil use from phase 1 to phase 2 , producing power above $40 \mu \mathrm{W}\left(7.9 \mathrm{~mW} / \mathrm{m}^{2}\right)$.

\subsection{Determination of the duration of bacterial incubation cycle in various types of soil}

The amount of electric power produced by a fuel cell is largely determined by the type and amount of bacteria. The more bacteria that are active on the surface of the anode electrode, the faster the oxidation-reduction (redox) reaction. The rate of this redox reaction has an impact on the amount of electricity produced (Rabaey \& Verstraete, 2005). According to Faraday's law, the amount of electric current produced depends on the transfer of electrons or the speed of reaction (Logan et al., 2006).

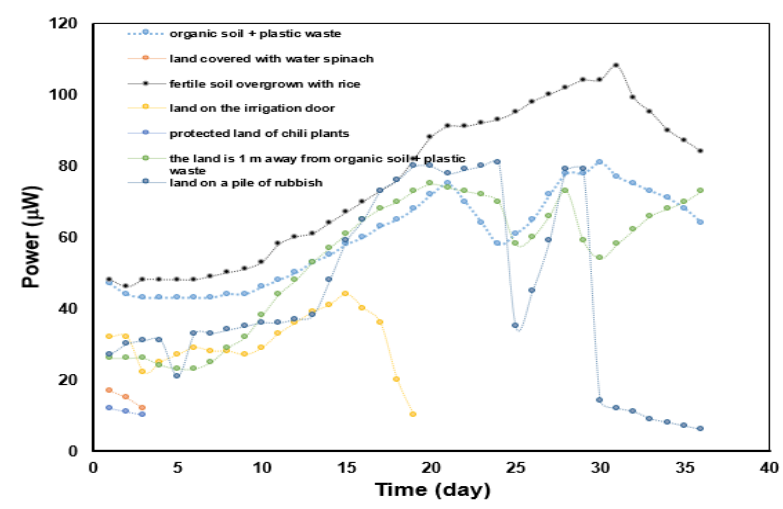

Fig. 3 Effect of incubation time on the power produced. 
Figure 3 shows two types of soil, namely, soil overgrown with water spinach and soil overgrown with chili plants, producing very little power. Bacteria in an MFC unit filled with these two types of soil can only survive for 3 days. The electricity produced is very small, which means that the number of bacteria active on the surface of the electrode is very small. On the other hand, the life span of only 3 days is caused by the very low nutrient content available. Figure 3 also shows the average power generated by the reactor during the study. Observations show that the maximum power values occur from the $15^{\text {th }}$ day to the $24^{\text {th }}$ day for each soil type, except the land on the irrigation door, which shows a continuous decline. After the $24^{\text {th }}$ day, three soil types show a decrease except for one type (i.e. fertile soil overgrown with rice) which shows an increase until the $31^{\text {st }}$ day.

Unlike other types of soil, the soil found $1 \mathrm{~m}$ away from organic soil and plastic waste and the soil on a pile of rubbish had a much longer cycle time of 35 days. Of the four types of soil, the unit filled with fertile soil overgrown with rice produced the largest electric power of $118 \mu \mathrm{W}$ $\left(23.4 \mathrm{~mW} / \mathrm{m}^{2}\right)$, followed by units filled with organic and plastic waste soil and soil media piled up with trash, which produced the same power of $80 \mu \mathrm{W}\left(15.8 \mathrm{~mW} / \mathrm{m}^{2}\right)$. On the other hand, a unit filled with soil found $1 \mathrm{~m}$ away from the organic soil and plastic waste produced power below 80 $\mu \mathrm{W}$. Meanwhile, for units filled with soil found on the irrigation door, this unit only produced approximately 40 $\mu \mathrm{W}\left(7.9 \mathrm{~mW} / \mathrm{m}^{2}\right)$ of power, with a cycle period of 19 days or half the period of the four types above.

Using various types of soil as MFC media where bacteria are active, as well as the diffusion of protons (Du et al., 2007) leading to the cathode, produced variations in the incubation period (i.e. 3-35 days) and the power density $\left(2.2-22.4 \mathrm{~mW} / \mathrm{m}^{2}\right.$ when measured directly with MudWatt and $140 \mu \mathrm{W} / \mathrm{m}^{2}$ when measured using the polarization method) as shown in Table 1. However, other research results show an incubation period of 6-9 days (Goto \& Yoshida, 2016). When compared with the incubation periods in the literature, those found in this study have a very significant difference, where values can reach up to $1156 \%$. However, measurements of power density show almost the same results (i.e. approaching 23 $\mu \mathrm{W} / \mathrm{m}^{2}$ ) despite using different types of soil media for the MFC units. The four types of soil produced large power density values as compared to the three types of soil media that used microorganisms, ranging between $29 \%$ and $88 \%$.

\subsection{Effect of adding green bean sprouts waste}

From the seven MFC units that showed bacterial activity, only two units can become fuel cell candidates. The first candidate was an MFC unit that was filled with soil media originating from fertile soil planted with rice. Figure.4 shows that this MFC unit produced more electric power after adding nutrients. The power produced was only 108 $\mu \mathrm{W}$ before any nutrients were added, but after adding nutrients, power increased to $122 \mu \mathrm{W}\left(24.2 \mathrm{~mW} / \mathrm{m}^{2}\right)$, indicating a power increase of $14 \mu \mathrm{W}\left(2.8 \mathrm{~mW} / \mathrm{m}^{2}\right)$. Then, after 10 days of adding nutrients to generate electric power, power decreased to a value of $20 \mu \mathrm{W}$, with an incubation period of approximately 50 days. Meanwhile the second candidate was an MFC unit that was filled with soil media from land that was stacked with organic waste. This unit produced $104 \mu \mathrm{W}$ of power, with an incubation period of 20 days, indicating that the life cycle of bacteria in this unit is much shorter compared to the first MFC unit.

The next cycle for the MFC unit containing land on pile of rubbish can still produce a power value of $109 \mu \mathrm{W}$ $\left(21.6 \mathrm{~mW} / \mathrm{m}^{2}\right)$, which is slightly larger than the first cycle. The second bacterial life cycle takes longer than the first cycle because of the availability of more nutrients. However, the power produced remains lower than that of the first MFC unit. One possible reason would be the different types of bacteria that are active on the surface of the electrode, despite the fact that the amount of nutrients given to the MFC unit is the same. If Figure 4 is carefully analyzed, we will be able to map the cycle power density, as shown in Table 2.

Among the various types of soil that can be used as bacterial growth media in MFCs after maximum incubation, three types of soil are suitable media candidates for making MFCs. The three types of soil are organic soil and plastic waste, land on a pile of rubbish, and fertile soil overgrown with rice. Table 1 shows that land on a pile of rubbish gives the result of a more stable power profile compared to the other types of soil (Goto \& Yoshida, 2016). The repetition cycle of adding nutrients produces the best reproducibility $\left(22.4-23.4 \mathrm{~mW} / \mathrm{m}^{2}\right)$ in electric power. This means that this type of environment provides a suitable environment with organic material reducing bacteria as an electron producer.

Table 1

Comparison of observations of the incubation period and power density to the literature (Khater et al., 2017)

\begin{tabular}{|l|lcccc}
\hline No & \multicolumn{1}{c}{ Type of Soil } & $\begin{array}{c}\text { Incubation Period } \\
(\mathbf{D a y})\end{array}$ & $\begin{array}{c}\text { Power } \\
(\boldsymbol{\mu} \mathbf{W})\end{array}$ & $\begin{array}{c}\text { Percentage of } \\
\text { Incubation Period }(\mathbf{\%})\end{array}$ & $\begin{array}{c}\text { Power Density } \\
\left(\mathbf{m W} / \mathbf{m}^{2}\right)\end{array}$ \\
\hline 1 & Organic soil + plastic Waste & 35 & 80 & 789 & 15.9 \\
2 & Land covered with water spinach & 3 & 13 & 44 & 2.6 \\
3 & Fertile soil overgrown with rice & 35 & 113 & 1156 & 22.4 \\
4 & Land on the irrigation door & 18 & 42 & 367 & 8.3 \\
5 & Protected land chili plants & 3 & 11 & 22 & 2.2 \\
6 & The land is 1 m way from organic + plastic waste & 35 & 75 & 733 & 14.9 \\
7 & Land on a pile of Rubbish & 30 & 80 & 789 & 15.9 \\
\hline
\end{tabular}


Table 2

Effect of adding green bean sprout waste

\begin{tabular}{lllc}
\hline No & Type of soil & Power /Power Density & Number of cycles (20 days) \\
\hline 1 & Organic Soil + Plastic Waste & $75 \mathrm{uW}\left(14.9 \mathrm{~mW} / \mathrm{m}^{2}\right)$ & 1 \\
2 & Land on a pile of rubbish & $113-18 \mathrm{uW}\left(22.4-23.4 \mathrm{~mW} / \mathrm{m}^{2}\right)$ & $>3$ \\
3 & Fertile soil overgrown with rice & $80-122 \mathrm{uW}\left(15.8-24.2 \mathrm{~mW} / \mathrm{m}^{2}\right)$ & 2
\end{tabular}

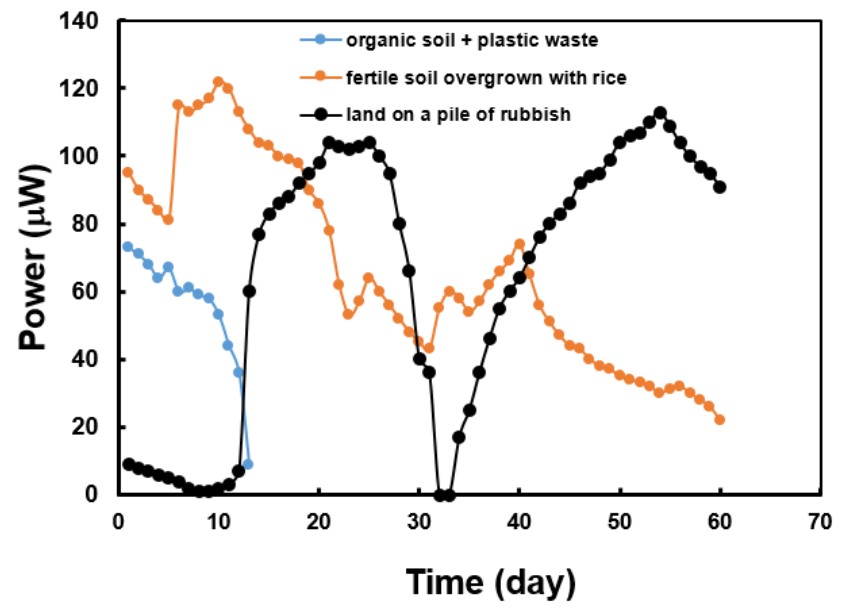

Fig 4. Effect of adding nutrients to bacterial activity in MFCs

Furthermore, the relationship between potential and current density can be explained by the maximum power density that can be produced by MFCs, as shown in Figure 5 . Figure 5 shows the characteristics of voltage, current density, and power density of MFCs with a single chamber. A felt-type graphite electrode with a thickness of $1 \mathrm{~cm}$ is used as a cathode, and felt-type graphite electrode with a thickness of $0.5 \mathrm{~cm}$ is used in the anodic space. Figure 5 shows the current density and maximum power density in MFCs with soil media from river sediments that are larger than those using paddy soil media. The difference between the two values is close to $20 \mathrm{~mW} / \mathrm{m}^{2}$, at a voltage of about $0.5 \mathrm{~V}$.

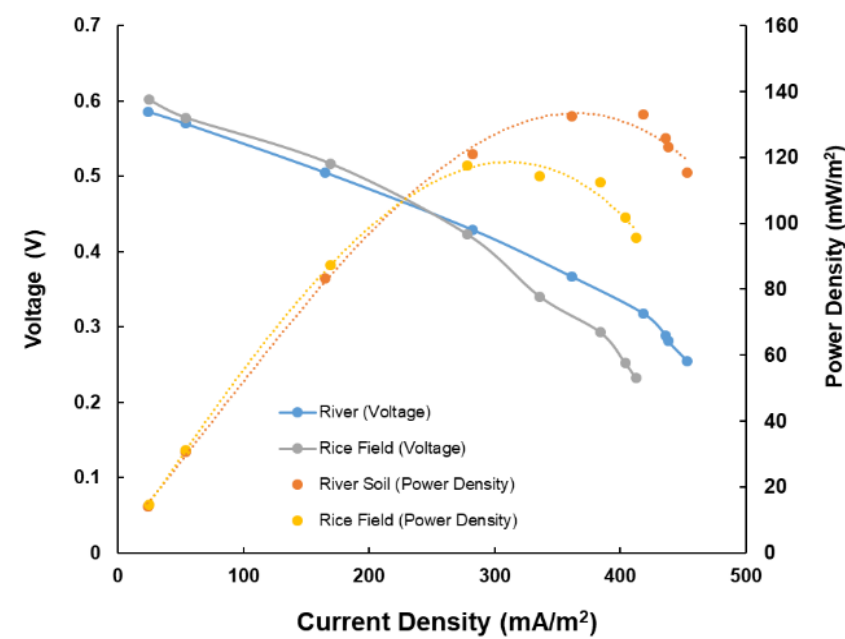

Fig 5. Relationship between polarization and power density to the current density produced by MFCs using soil media from river and rice field.
The results of this study indicate that the maximum power density values that were obtained were higher $\left(120-140 \mathrm{~mW} / \mathrm{m}^{2}\right)$ than those achieved by Lorenso $(80.3$ $\left.\mathrm{mW} / \mathrm{m}^{2}\right)$, Liu et al., $2004\left(25 \mathrm{~mW} / \mathrm{m}^{2}\right)$, and Vilas Boas et al. $\left(5.04 \mathrm{~mW} / \mathrm{m}^{2}\right)$. These results will show that certain soil types produce high power density values.

Unique fuel cell electrochemical resistance models can be applied to explain MFC models, which can be expressed as follows (Zaidi \& Rauf, 2009):

$$
\mathrm{E}=\mathrm{E}^{o}-(\alpha+\beta \ln i)-R_{\Omega} i
$$

where $\mathrm{E}^{\circ}$ is the standard potential; $\mathrm{E}$ is the potential of cell electrodes, $\alpha$ and $\beta$ are the terms for system or internal resistance, respectively; and $i$ is the current density based on the anode area.

Figure 5 was further analyzed, and the final results that were obtained are shown in Figure 6. We divided the polarization curve area into three: activation loss, ohmic loss, and concentration loss (Kadivarian \& Karamzadeh, 2020).

The existence of these three regions affects the effective voltage of the MFC. Furthermore, the three values from the area result in a reduction in the value of the voltage. By comparing the two curves above, results show that the effective voltage $\left(\mathrm{V}_{\text {eff }}\right)$ of the MFC with river ground media $(0.27 \mathrm{~V})$ is greater than that of the MFC with paddy soil media $(0.20 \mathrm{~V})$. The higher the $\mathrm{V}_{\text {eff }}$, the higher the power generated. To calculate the $V_{\text {eff }}$ of the $\mathrm{MFC}$, we use the following equation:

$$
\mathrm{V}=\mathrm{OCV}-\eta_{\text {act }}-\eta_{\mathrm{ohm}}-\eta_{\text {concen }}
$$

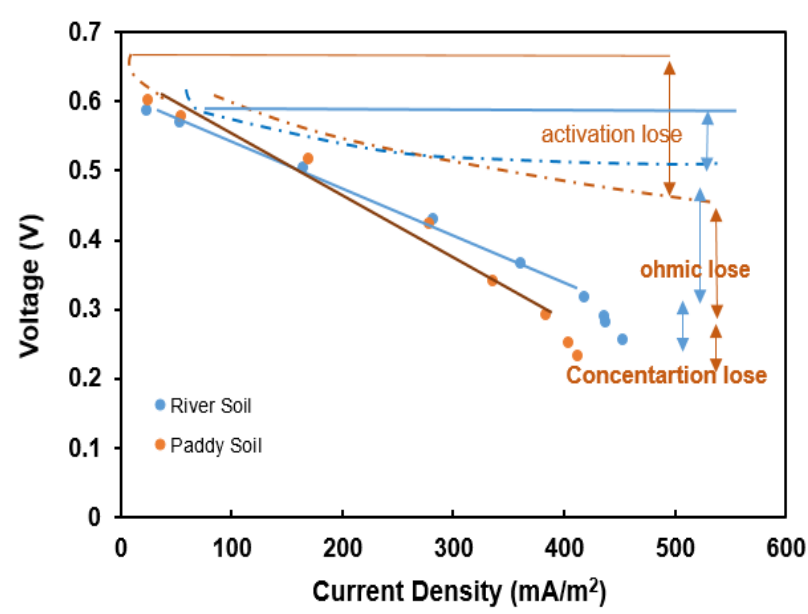

Fig 6. Analysis results of the polarization curve of a singlechamber MFC 
These terms represent the open-circuit voltage, activation voltage loss on the electrodes, voltage loss due to soil media resistance (soil conductivity), and voltage loss due to changes in substrate concentration consumed by microbes, respectively (Yasri et al., 2019), (Kadivarian \& Karamzadeh, 2020).

\section{Conclusion}

The type of soil media can greatly influence the electric power generated and the incubation period of the MFC unit. Soil types that contain organic matter produce more power density than ordinary soil types that have low organic matter content. An MFC can be regenerated to produce more power than previously untreated land. The maximum power density of $22.4-23.4 \mathrm{~mW} / \mathrm{m}^{2}$ was produced by an MFC with rice field soil, which contains a lot of organic waste with a life cycle $>3$ (20 days) after the addition of glucose nutrition. More research are still needed to study various types of substrate or types of agricultural waste to get greater power density values and longer life cycles.

\section{Acknowledgment}

This research was partially supported by a grant from the IDB 2018 research of the University of Jember. Physical chemistry technical assistance was provided on automated instrumentation and electronic equipment.

\section{References}

Aelterman, P., Freguia, S., Keller, J., Verstraete, W., \& Rabaey, K. (2008). The anode potential regulates bacterial activity in microbial fuel cells. Applied Microbiology and Biotechnology, 78(3), 409-418. DOI: 10.1007/s00253-0071327-8

Asai, Y., Miyahara, M., Kouzuma, A., \& Watanabe, K. (2017). Comparative evaluation of wastewater-treatment microbial fuel cells in terms of organics removal, wastesludge production, and electricity generation. Bioresources and Bioprocessing, 4(1). DOI:10.1186/s40643-017-0163-7

Baranitharan, E., Khan, M. R., Prasad, D. M. R., Teo, W. F. A., Tan, G. Y. A., \& Jose, R. (2015). Effect of biofilm formation on the performance of microbial fuel cell for the treatment of palm oil mill effluent. Bioprocess and Biosystems Engineering, 38(1), 15-24. DOI:10.1007/s00449-014-12399

Biffinger, J. C., Ray, R., Little, B., \& Ringeisen, B. R. (2007). Diversifying biological fuel cell designs by use of nanoporous filters. Environmental Science and Technology, 41(4), 1444-1449. DOI: 10.1021/es061634u

Cao, W., Luo, Q., \& Shen, Ya Ling, D. Z. (2006). Optimization of culture on the overproduction of TRAIL in high-cell-density culture by recombinant Escherichia coli. Applied Microbiology and Biotechnology, 71(2), 184-191. DOI: 10.1007/s00253-005-0131-6

Chaturvedi, V., \& Verma, P. (2016). Microbial fuel cell: a green approach for the utilization of waste for the generation of bioelectricity. Bioresources and Bioprocessing, 3(1). DOI: 10.1186/s40643-016-0116-6

Cheng, S., Xing, D., \& Logan, B. E. (2011). Electricity generation of single-chamber microbial fuel cells at low temperatures. Biosensors and Bioelectronics, 26(5), 1913-1917. DOI: 10.1016/j.bios.2010.05.016

Choudhury, P., Prasad Uday, U. S., Bandyopadhyay, T. K., Ray, R. N., \& Bhunia, B. (2017). Performance improvement of microbial fuel cell (MFC) using suitable electrode and Bioengineered organisms: A review. Bioengineered, 8(5), 471-487. DOI: 10.1080/21655979.2016.1267883

Du, Z., Li, H., \& Gu, T. (2007). A state of the art review on microbial fuel cells: A promising technology for wastewater treatment and bioenergy. Biotechnology Advances, 25(5), 464-482. DOI: 10.1016/j.biotechadv.2007.05.004

Fosso-kankeu, E., Marx, S., Waanders, F., \& Jacobs, V. (2015). Impact of soil type on electricity generation from a Microbial Fuel Cell. DOI: 10.15242/iie.e1115020

Goto, Y., \& Yoshida, N. (2016). Preliminary evaluation of a microbial fuel cell treating artificial dialysis wastewater using graphene oxide. AIP Conference Proceedings, 1709(February). DOI: 10.1063/1.4941206

He, W., Zhang, X., Liu, J., Zhu, X., Feng, Y., \& Logan, B. E. (2016). Microbial fuel cells with an integrated spacer and separate anode and cathode modules. Environmental Science: Water Research and Technology, 2(1), 186-195. DOI: $10.1039 / \mathrm{c} 5 \mathrm{ew} 00223 \mathrm{k}$

Helder, M., Strik, D. P., Hamelers, H. V., \& Buisman, C. J. (2012). The flat-plate plant-microbial fuel cell: The effect of a new design on internal resistances. Biotechnology for Biofuels, 5. DOI: $10.1186 / 1754-6834-5-70$

Kadivarian, M., \& Karamzadeh, M. (2020). Electrochemical modeling of microbial fuel cells performance at different operating and structural conditions. Bioprocess and Biosystems Engineering, 43(3), 393-401. DOI: 10.1007/s00449-019-02235-1

Khater, D. Z., El-Khatib, K. M., \& Hassan, H. M. (2017). Microbial diversity structure in acetate single chamber microbial fuel cell for electricity generation. Journal of Genetic Engineering and Biotechnology, 15(1), 127-137. DOI:10.1016/j.jgeb.2017.01.008

Kim, J. R., Jung, S. H., Regan, J. M., \& Logan, B. E. (2007). Electricity generation and microbial community analysis of alcohol powered microbial fuel cells. Bioresource Technology, 98(13), 2568-2577. DOI: 10.1016/j.biortech.2006.09.036

Koók, L., Nemestóthy, N., Bélafi-Bakó, K., \& Bakonyi, P. (2020). Investigating the specific role of external load on the performance versus stability trade-off in microbial fuel cells. Bioresource Technology, 309(March). DOI: 10.1016/j.biortech.2020.123313

Liu, K. S. (2008). Food Use of Whole Soybeans. Soybeans: Chemistry, Production, Processing, and Utilization, 441481. DOI: 10.1016/B978-1-893997-64-6.50017-2

Liu, Z., Liu, J., Zhang, S., \& Su, Z. (2009). Study of operational performance and electrical response on mediator-less microbial fuel cells fed with carbon- and protein-rich substrates. Biochemical Engineering Journal, 45(3), 185191. DOI: $10.1016 /$ j.bej.2009.03.011

Logan, B. E., Hamelers, B., Rozendal, R., Schröder, U., Keller, J., Freguia, S., Aelterman, P., Verstraete, W., \& Rabaey, K. (2006). Microbial fuel cells: Methodology and technology. Environmental Science and Technology, 40(17), 51815192. DOI: $10.1021 / \mathrm{es} 0605016$

Logan, B. E., Murano, C., Scott, K., Gray, N. D., \& Head, I. M. (2005). Electricity generation from cysteine in a microbial fuel cell. Water Research, 39(5), 942-952. DOI: 10.1016/j.watres.2004.11.019

Logan, B. E., \& Rabaey, K. (2012). Conversion of wastes into bioelectricity and chemicals by using microbial electrochemical technologies. Science, 337(6095), 686-690. DOI: $10.1126 /$ science. 1217412

Logan, B. E., Wallack, M. J., Kim, K. Y., He, W., Feng, Y., \& Saikaly, P. E. (2015). Assessment of Microbial Fuel Cell Configurations and Power Densities. Environmental Science and Technology Letters, 2(8), 206-214. DOI: 10.1021/acs.estlett.5b00180

Marashi, S. K. F., \& Kariminia, H. R. (2015). Performance of a 
single chamber microbial fuel cell at different organic loads and $\mathrm{pH}$ values using purified terephthalic acid wastewater. Journal of Environmental Health Science and Engineering, 13(1), 1-6. DOI: 10.1186/s40201-015-0179-x

Min, B., \& Logan, B. (2004). Continuous Electricity Generation from Domestic Waste water and Organiic Substrates in a Flat Plate Microbial Fuel Cell. Environ. Sci. Technol., 38(21), 5809-5814. DOI: 10.1021/es0491026

Misto, Mulyono, T., Cahyono, B. E., \& Zain, T. (2019). Determining sugar content in sugarcane plants using LED spectrophotometer. AIP Conference Proceedings, 2202(December). DOI: 10.1063/1.5141738

Ömeroğlu, S., \& Sanin, F. D. (2016). Bioelectricity Generation From Wastewater Sludge Using Microbial Fuel Cells: A Critical Review. Clean - Soil, Air, Water, 44(9), 1225-1233. DOI: $10.1002 /$ clen.201500829

Pant, D., Van Bogaert, G., Porto-Carrero, C., Diels, L., \& Vanbroekhoven, K. (2011). Anode and cathode materials characterization for a microbial fuel cell in half cell configuration. Water Science and Technology, 63(10), 2457-2461. DOI: $10.2166 /$ wst.2011.217

Park, D. O. O. H. (2000). Electricity Generation in Microbial Fuel Cells Using Neutral Red as an Electronophore Downloaded from http://aem.asm.org/ on September 27, 2017 by INDIAN INST OF TECHNOLOGY Kharagpur. Applied Environmental Microbiology, 66(4), 1292-1297. DOI: 10.1128/AEM.66.4.1292-1297.2000.

Parkash, A. (2016). Microbial Fuel Cells: A Source of Bioenergy. Journal of Microbial \& Biochemical Technology, 8(3), 247255. DOI: $10.4172 / 1948-5948.1000293$

Rabaey, K., Lissens, G., Siciliano, S. D., \& Verstraete, W. (2003). A MFC capable of converting glucose to electricity at high rate and efficeincy.pdf. Biotechnology Letter, 25, 15311535 .

Rabaey, K., \& Verstraete, W. (2005). Microbial fuel cells: Novel biotechnology for energy generation. Trends in Biotechnology, 23(6), 291-298. DOI: 10.1016/j.tibtech.2005.04.008

Rahimnejad, M., Adhami, A., Darvari, S., Zirepour, A., \& Oh, S. E. (2015). Microbial fuel cell as new technol ogy for bioelectricity generation: A review. Alexandria Engineering Journal, 54(3), 745-756. DOI: 10.1016/j.aej.2015.03.031

Rolfe, M. D., Rice, C. J., Lucchini, S., Pin, C., Thompson, A., Cameron, A. D. S., Alston, M., Stringer, M. F., Betts, R. P., Baranyi, J., Peck, M. W., \& Hinton, J. C. D. (2012). Lag phase is a distinct growth phase that prepares bacteria for exponential growth and involves transient metal accumulation. Journal of Bacteriology, 194(3), 686-701. DOI: 10.1128/JB.06112-11

Shaheen Aziz, A. P. (2015). Utilization of Sewage Sludge for Production of Electricity using Mediated Salt Bridge Based Dual Chamber Microbial Fuel Cell. Journal of Bioprocessing \& Biotechniques, 05(08). DOI: 10.4172/21559821.1000251
Song, H.L., Zhu, Y., \& Li, J. (2019). Electron transfer mechanisms, characteristics and applications of biological cathode microbial fuel cells - A mini review. Arabian Journal of Chemistry, 12(8), 2236-2243. DOI: 10.1016/j.arabjc.2015.01.008

Sultana, S.T., Babauta, J. T., \& Beyenal, H. (2015). Electrochemical biofilm control: A review. Biofouling, 31(9), 745-758. DOI: 10.1080/08927014.2015.1105222

Tharali, A. D., Sain, N., \& Osborne, W. J. (2016). Microbial fuel cells in bioelectricity production. Frontiers in Life Science, 9(4), 252-266. DOI: 10.1080/21553769.2016.1230787

Totsche, K. U., Amelung, W., Gerzabek, M. H., Guggenberger, G., Klumpp, E., Knief, C., Lehndorff, E., Mikutta, R., Peth, S., Prechtel, A., Ray, N., \& Kögel-Knabner, I. (2018). Microaggregates in soils. Journal of Plant Nutrition and Soil Science, 181(1), 104-136. DOI: 10.1002/jpln.201600451

Ucar, D., Zhang, Y., \& Angelidaki, I. (2017). An overview of electron acceptors in microbial fuel cells. Frontiers in Microbiology, $\quad$ 8(APR), $\quad 1-14 . \quad$ DOI: 10.3389/fmicb.2017.00643

Wrighton, K. C., Virdis, B., Clauwaert, P., Read, S. T., Daly, R. A., Boon, N., Piceno, Y., Andersen, G. L., Coates, J. D., \& Rabaey, K. (2010). Bacterial community structure corresponds to performance during cathodic nitrate reduction. ISME Journal, 4(11), 1443-1455. DOI: 10.1038/ismej.2010.66

Xia, C., Xu, M., Liu, J., Guo, J., \& Yang, Y. (2017). Corrigendum to "Sediment microbial fuel cell prefers to degrade organic chemicals with higher polarity" (Bioresour Technol. 190 (2015) 420-423) (S0960852415005799) (10.1016/j.biortech.2015.04.072). Bioresource Technology, 226, 272. DOI: 10.1016/j.biortech.2016.12.066

Xu, L., Zhao, Y., Doherty, L., Hu, Y., \& Hao, X. (2016). The integrated processes for wastewater treatment based on the principle of microbial fuel cells: A review. Critical Reviews in Environmental Science and Technology, 46(1), 60-91. DOI: 10.1080/10643389.2015.1061884

Yasri, N., Roberts, E. P. L., \& Gunasekaran, S. (2019). The electrochemical perspective of bioelectrocatalytic activities in microbial electrolysis and microbial fuel cells. Energy Reports, 5, 1116-1136. DOI: 10.1016/j.egyr.2019.08.007

Zaidi, S. M. J., \& Rauf, M. A. (2009). Fuel cell fundamentals. In Polymer Membranes for Fuel Cells. DOI: 10.1007/978-0387-73532-0_1

Zhang, E., Liu, L., \& Cui, Y. (2013). Effect of $\mathrm{pH}$ on the performance of the anode in microbial fuel cells. Advanced Materials Research, 608-609, 884-888. DOI: 10.4028/www.scientific.net/AMR.608-609.884

Zhang, T., Zeng, Y., Chen, S., Ai, X., \& Yang, H. (2007). Improved performances of E. coli-catalyzed microbial fuel cells with composite graphite/PTFE anodes. Electrochemistry Communications, $9(3), \quad 349-353 . \quad$ DOI: 10.1016/j.elecom.2006.09.025 